\begin{tabular}{|c|l|}
\hline Title & Catalytic asymmetric synthesis of descurainin via 1,3-dipolar cycloaddition of a carbonyl ylide using Rh2(R-TCPTTL)4 \\
\hline Author(s) & Shimada, Naoyuki; Hanari, Taiki; Kurosaki, Y asunobu; A nada, Masahiro; Nambu, Hisanori; Hashimoto, Shunichi \\
\hline Citation & $\begin{array}{l}\text { Tetrahedron Letters, 51(50), 6572-6575 } \\
\text { https:/doi.org/40.1016j.tetlet.2010.10.036 }\end{array}$ \\
\hline Issue Date & 2010 -12-15 \\
\hline Doc URL & http://hdl.handle.net/2115/44674 \\
\hline Type & article (author version) \\
\hline File Information & TL51-50_6572-6575.pdf \\
\hline
\end{tabular}

Instructions for use 
Graphical Abstract

To create your abstract, type over the instructions in the template box below.

Fonts or abstract dimensions should not be changed or altered.

Catalytic asymmetric synthesis of descurainin via 1,3-dipolar cycloaddition of a carbonyl ylide using $\mathbf{R h}_{\mathbf{2}}(\boldsymbol{R} \text {-TCPTTL })_{4}$

Naoyuki Shimada, Taiki Hanari, Yasunobu Kurosaki, Masahiro Anada, Hisanori Nambu, Shunichi Hashimoto*
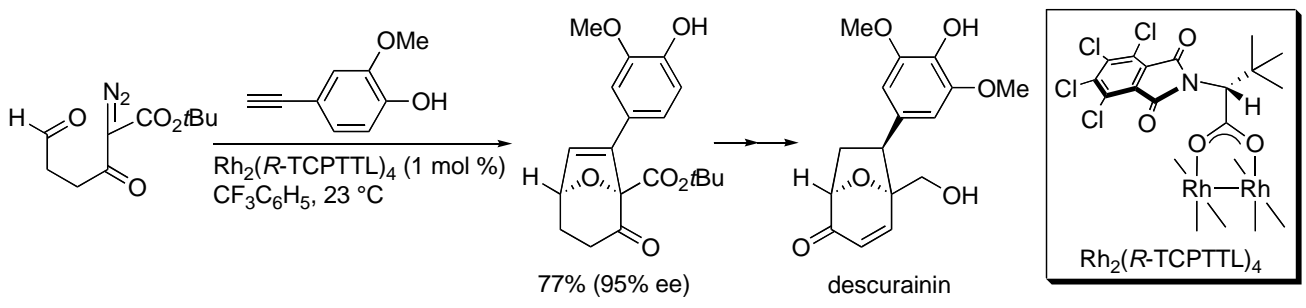


\title{
Catalytic asymmetric synthesis of descurainin via 1,3-dipolar cycloaddition of a carbonyl ylide using $R_{2}(R-T C P T T L)_{4}$
}

\author{
Naoyuki Shimada, Taiki Hanari, Yasunobu Kurosaki, Masahiro Anada, Hisanori Nambu, \\ Shunichi Hashimoto*
}

Faculty of Pharmaceutical Sciences, Hokkaido University, Sapporo 060-0812, Japan

\section{ARTICLE INFO}

Article history:

Received

Received in revised form

Accepted

Available online

\section{Keywords:}

Carbonyl ylide

1,3-Dipolar cycloaddition

Chiral dirhodium(II) catalyst

Descurainin

\section{ABSTRACT}

A catalytic asymmetric synthesis of descurainin has been achieved by incorporating an enantioselective 1,3-dipolar cycloaddition, a stereoselective alkene hydrogenation, an oxidation with Fremy's salt and a regioselective demethylation with $\mathrm{NbCl}_{5}$ as the key steps. The 1,3dipolar cycloaddition of a carbonyl ylide derived from tert-butyl 2-diazo-5-formyl-3oxopetanoate with 4-hydroxy-3-methoxyphenylacetylene in the presence of dirhodium(II) tetrakis[ $N$-tetrachlorophthaloyl- $(R)$-tert-leucinate $], \quad \mathrm{Rh}_{2}(R \text {-TCPTTL })_{4}, \quad$ provided an 8 oxabicyclo[3.2.1] octane skeleton in $95 \%$ ee.
In 2004, Li and co-workers isolated descurainin (1) from the seeds of Descurainia sophia (L.) Webb ex Prantl, which are widely used as Chinese traditional medicine to relieve coughing, prevent asthma, reduce edema and promote urination. ${ }^{1}$ Compound $\mathbf{2}^{2}$ and cartorimine $(\mathbf{3}),{ }^{3}$ possessing an 8oxabicylo[3.2.1] oct-3-en-2-one ring system, were isolated from Ligusticum chuanxing Hort. and Carthamus tinctorius L. by the Wen and He groups, respectively. Snider and Grabowski reported a concise total synthesis of $( \pm)-\mathbf{1}-\mathbf{3}$, in which the fully functionalized 8-oxabicyclo[3.2.1]octenone skeleton was efficiently constructed by a possible biomimetic [5+2] cycloaddition of oxidopyrylium ion. ${ }^{4}$

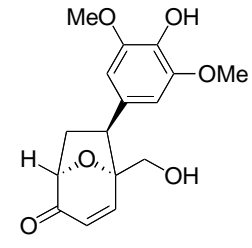

descurainin (1)

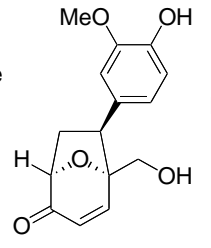

2

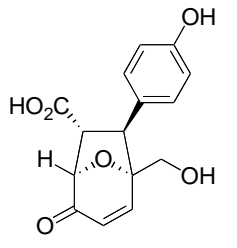

cartorimine (3)
The dirhodium(II) complex-catalyzed tandem cyclic carbonyl ylide formation-1,3-dipolar cycloaddition reaction sequence represents one of the most powerful methods for the rapid assembly of complex oxapolycyclic systems. ${ }^{5-8}$ An

* Corresponding author. Tel.: +81-11-706-3236; fax: +81-11-7064981; e-mail: hsmt@ pharm.hokudai.ac.jp (S. Hashimoto). enantioselective version of this sequence catalyzed by chiral dirhodium(II) complexes has also been developed. ${ }^{9-12}$ Recently, we reported an enantioselective 1,3-dipolar cycloaddition of a six-membered cyclic formyl-carbonyl ylide with phenylacetylene derivatives using dirhodium(II) tetrakis[ $N$-tetrachlorophthaloyl(S)-tert-leucinate], $\mathrm{Rh}_{2}(S \text {-TCPTTL })_{4}(\mathbf{4}),{ }^{13-15}$ as a catalyst. ${ }^{16}$ The reaction between tert-butyl 2-diazo-5-formyl-3-oxopetanoate (6) and 4-hydroxy-3-methoxyphenylacetylene (7) provided 8oxabicyclo[3.2.1] octane derivative 8 in $73 \%$ yield with $95 \%$ ee (Eq. 1). Using this catalytic methodology, we achieved the first asymmetric synthesis of ent-2. ${ }^{16}$ The absolute maximal molar circular dichroism of synthetic material ent-2 $(\Delta \varepsilon-3.81$ at 348 $\mathrm{nm})$ displayed a startling difference in magnitude to that of natural product $\mathbf{2}(\Delta \varepsilon+0.01$ at $355 \mathrm{~nm})$. $^{2}$ This observation

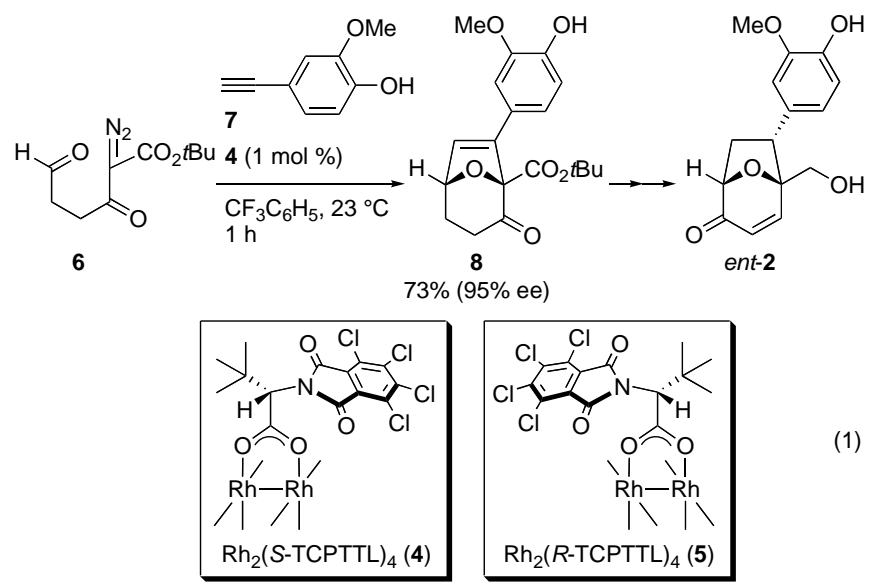


suggested that natural product 2 might be biosynthesized in nearracemic form like polygalolides $\mathrm{A}$ and $\mathrm{B} .{ }^{17,18}$ Our results provided experimental support for the biogenetic hypothesis by Snider's group. ${ }^{4 \mathrm{~b}}$ As an extension of our study in this field, we herein report an asymmetric synthesis of descurainin (1) using the carbonyl ylide cycloaddition methodology.

Our synthetic strategy is outlined retrosynthetically in Scheme 1 . We envisaged that $\mathbf{1}$ would be accessible from $\beta$-ketoester $\mathbf{9}$, which would be derived from bicyclic compound $\mathbf{1 0}$ in a stereocontrolled manner. On the basis of our previous work, ${ }^{16}$ we envisioned that the cycloaddition of a carbonyl ylide derived from $\alpha$-diazo- $\beta$-ketoester 6 with phenylacetylene derivative 11 using $\mathrm{Rh}_{2}(R \text {-TCPTTL })_{4}(\mathbf{5}){ }^{19}$ would provide cycloadduct $\mathbf{1 0}$.

Toward this end, we initially examined the reaction of $\alpha$ diazo- $\beta$-ketoester $\mathbf{6}^{16}$ with a variety of 3,5-dimethoxy-4hydroxyphenylacetylene derivatives $\mathbf{1 1 a}-\mathbf{d}$ in the presence of 1 mol \% of $\mathrm{Rh}_{2}(R \text {-TCPTTL })_{4}(5)$ in $\alpha, \alpha, \alpha$-trifluorotoluene at room temperature (Table 1, entries 1-4). The reaction of 6 with phenylacetylene 11a bearing a free phenolic hydroxy group gave cycloadduct 12a in $55 \%$ yield (entry 1 ). The enantiomeric excess of 12a was determined to be $50 \%$ by HPLC using a Chiralcel OD-H column. Switching the dipolarophile to tertbutyldimethylsilyl (TBS)- or methyl-protected phenylacetylenes
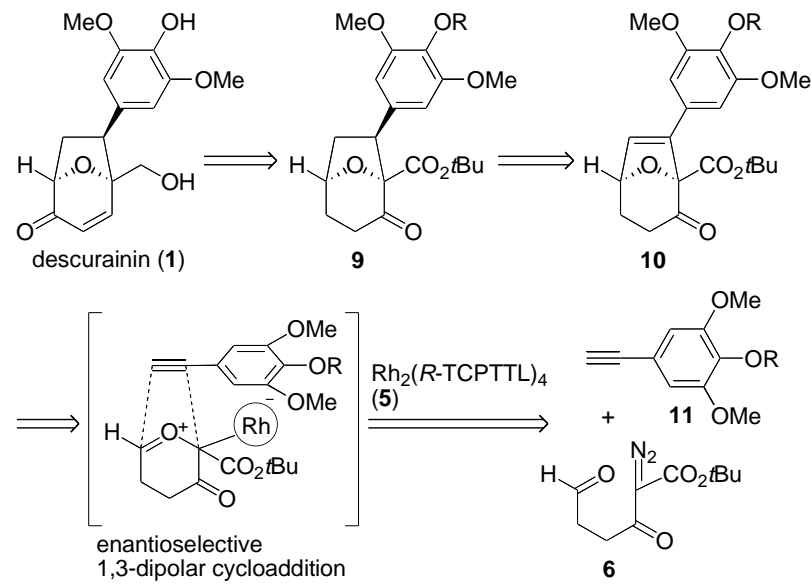

Scheme 1. Retrosynthetic analysis of descurainin (1).

Table 1

Enantioselective 1,3-dipolar cycloaddition of a carbonyl ylide derived from 6 with $11 a-d$ and 7 using $\mathrm{Rh}_{2}(R \text {-TCPTTL })_{4}(\mathbf{5})^{\mathrm{a}}$

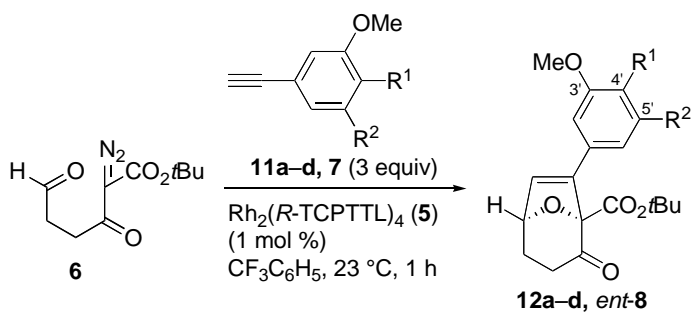

\begin{tabular}{llllllll}
\hline & \multicolumn{3}{c}{ dipolarophile } & & \multicolumn{3}{c}{ product } \\
\cline { 2 - 3 } \cline { 6 - 7 } entry & & $\mathrm{R}^{1}$ & $\mathrm{R}^{2}$ & & & Yield $^{\mathrm{b}}(\%)$ & $\mathrm{ee}^{\mathrm{c}}(\%)$ \\
\hline 1 & 11a & OH & OMe & & 12a & 55 & 50 \\
2 & 11b & OTBS & OMe & & 12b & 39 & 26 \\
3 & 11c & OMe & OMe & & $\mathbf{1 2 c}$ & 44 & 20 \\
4 & 11d & OAc & OMe & & $\mathbf{1 2 d}$ & 62 & 1 \\
$5^{\text {d }}$ & $\mathbf{7}$ & OH & H & & ent-8 & 77 & 95 \\
\hline
\end{tabular}

${ }^{a}$ Unless otherwise noted, reactions were carried out as follows: a solution of 6 (45.3 mg, $0.2 \mathrm{mmol}$ ) and dipolarophile (3 equiv) in $\mathrm{CF}_{3} \mathrm{C}_{6} \mathrm{H}_{5}(1 \mathrm{~mL})$ was added over $1 \mathrm{~h}$ to a stirred solution of $\mathrm{Rh}_{2}(R \text {-TCPTTL })_{4}(\mathbf{5})(3.95 \mathrm{mg}, 1$ mol \%) in $\mathrm{CF}_{3} \mathrm{C}_{6} \mathrm{H}_{5}(1 \mathrm{~mL})$ at $23{ }^{\circ} \mathrm{C}$.

${ }^{\mathrm{b}}$ Isolated yield.

${ }^{\mathrm{c}}$ Determined by HPLC. See the Supplementary data for details.

${ }^{\mathrm{d}}$ The reaction was performed on a $7.0 \mathrm{mmol}$ scale, in which the addition time was $3 \mathrm{~h}$. 11b and 11c resulted in a noticeable drop in both product yields (39\% and 44\%, respectively) and enantioselectivities (26\% ee and $20 \%$ ee, respectively) compared to those with 11a (entries 2 and 3). The use of acetyl-protected phenylacetylene 11d caused a sharp drop in enantioselectivity, though cycloadduct 12d was obtained in good yield ( $62 \%$ yield, $1 \%$ ee, entry 4$)$. It is noteworthy that the steric and electronic nature of dipolarophiles markedly influenced both product yield and enantioselectivity. ${ }^{10 b, c}$ These unsatisfactory results led us to change our strategy. We envisioned that the enantiomer of bicyclic compound 8 possessing a 4'-hydroxy-3'-methoxybenzene ring would be an intermediate for the synthesis of $\mathbf{1}$ via installation of a methoxy group at the $\mathrm{C}^{\prime}$ position on the aromatic ring. Thus, the reaction of $\mathbf{6}$ with 4-hydroxy-3methoxyphenylacetylene (7) as a dipolarophile in the presence of $\mathrm{Rh}_{2}(R \text {-TCPTTL })_{4}(\mathbf{5})$ was performed to provide the desired cycloadduct ent-8, $[\alpha]_{\mathrm{D}}^{22}-148.5\left(c 1.09, \mathrm{CHCl}_{3}\right)$, in $77 \%$ yield with virtually the same enantioselectivity $(95 \%$ ee) as those found in our previous study (entry 5). ${ }^{16,20}$

Catalytic hydrogenation of ent-8 provided exclusively the desired endo-bicyclic compound $\mathbf{1 3}$ as a single diastereomer in $99 \%$ yield (Scheme 2). ${ }^{21}$ We then investigated installation of a hydroxy group at the $\mathrm{C} 5^{\prime}$ position on the aromatic ring via formation of $o$-quinone. Treatment of phenol 13 with $\left(\mathrm{KSO}_{3}\right)_{2} \mathrm{NO}$ (Fremy's salt) ${ }^{22}$ in the presence of $\mathrm{KH}_{2} \mathrm{PO}_{4}$ gave $o$-quinone 14. Keeping the reaction time short prevented significant loss of product yield. The resultant $o$-quinone $\mathbf{1 4}$ was immediately converted into catechol 15 by treatment with $\mathrm{Na}_{2} \mathrm{~S}_{2} \mathrm{O}_{4}$ in $73 \%$ yield in two steps from 13. ${ }^{23}$ Since attempts at regioselective methylation of $\mathbf{1 5}$ were unsuccessful, ${ }^{24}$ we turned our attention to the viability of a regioselective demethylation of trimethoxybenzene derivative. Treatment of $\mathbf{1 5}$ with MeI (4 equiv.) and $\mathrm{K}_{2} \mathrm{CO}_{3}$ afforded per-methylated product 16 in quantitative yield.

With an efficient installation of a methoxy group at the C5' position realized, the stage was now set for completion of the asymmetric synthesis of $\mathbf{1}$ as illustrated in Scheme 3. Treatment of ketone 16 with NaHMDS at $-78{ }^{\circ} \mathrm{C}$ followed by addition of $\mathrm{PhNTf}_{2}$ and subsequent palladium-catalyzed reduction of the resulting enol triflate ${ }^{25}$ furnished alkene $\mathbf{1 7}$ in $81 \%$ yield. Reduction of $\mathbf{1 7}$ with $\mathrm{LiAlH}_{4}$ provided alcohol $\mathbf{1 8}$ in quantitative yield. Next, regioselective demethylation of $\mathbf{1 8}$ was investigated under a variety of conditions. This transformation turned out to be even more difficult than we anticipated, as the bicyclic component was prone to decomposition under acidic conditions ( $\mathrm{HBr}$, TMSI, $\mathrm{MeSO}_{3} \mathrm{H} / \mathrm{NaI}$ or $\mathrm{BF}_{3} \cdot \mathrm{OEt}_{2} / \mathrm{NaI}$ ) frequently used in

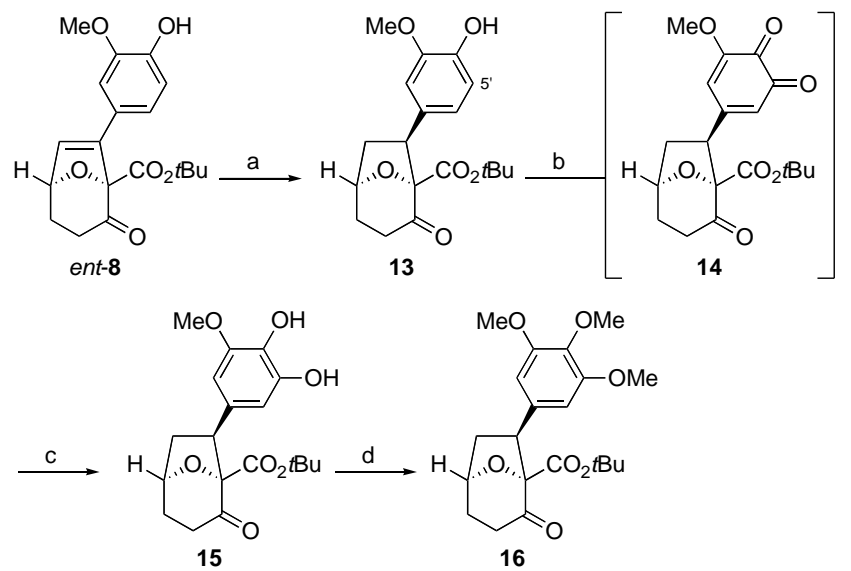

Scheme 2. Reagents and conditions: (a) $\mathrm{H}_{2}, 10 \% \mathrm{Pd} / \mathrm{C}, \mathrm{MeOH}, 1 \mathrm{~h}, 99 \%$; (b) $\left(\mathrm{KSO}_{3}\right)_{2} \mathrm{NO}, \mathrm{KH}_{2} \mathrm{PO}_{4}$, acetone $/ \mathrm{H}_{2} \mathrm{O}(3: 1), 10 \mathrm{~min}$; (c) $\mathrm{Na}_{2} \mathrm{~S}_{2} \mathrm{O}_{4}, \mathrm{KH}_{2} \mathrm{PO}_{4}$, EtOAc/ $\mathrm{H}_{2} \mathrm{O}$ (5:1), 0.5 h, $73 \%$ (two steps); (d) $\mathrm{MeI}, \mathrm{K}_{2} \mathrm{CO}_{3}$, acetone, reflux, 1 h. $99 \%$. 


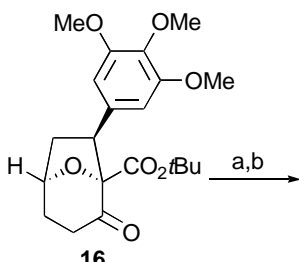

16

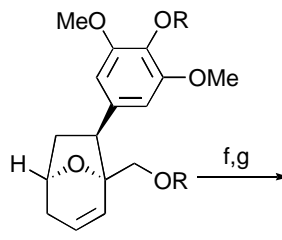

$\longrightarrow$ 20: $R=$ TBDPS e 19: $\mathrm{R}=\mathrm{H}$

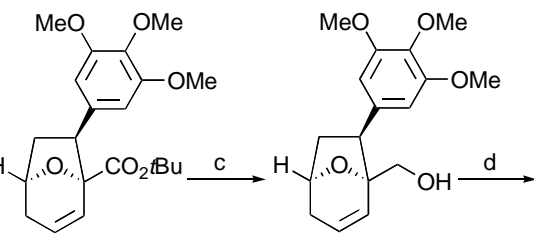

18$$
17
$$

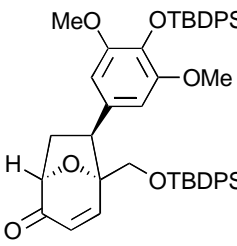

21

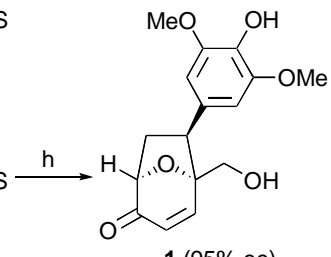

$1(95 \%$ ee)

$[\alpha]_{D}^{23}+327.5(c 0.55, \mathrm{MeOH})$

lit. $^{1}[\alpha]_{D}^{23}+1.7(c 0.23, \mathrm{MeOH})$
Scheme 3. Reagents and conditions: (a) NaHMDS, THF, $-78{ }^{\circ} \mathrm{C}, 1 \mathrm{~h}$, then, $\mathrm{PhNTf}_{2},-78$ to $-10{ }^{\circ} \mathrm{C}, 3 \mathrm{~h}, 96 \%$; (b) $\mathrm{Pd}(\mathrm{OAc})_{2}, \mathrm{PPh}_{3}, n \mathrm{Bu}_{3} \mathrm{~N}, \mathrm{HCO}_{2} \mathrm{H}, \mathrm{DMF}$ $60{ }^{\circ} \mathrm{C}, 40 \mathrm{~min}, 84 \%$; (c) $\mathrm{LiAlH}_{4}, \mathrm{THF}, 0{ }^{\circ} \mathrm{C}, 1.5 \mathrm{~h}, 99 \%$; (d) $\mathrm{NbCl}_{5}$, $\mathrm{ClCH}_{2} \mathrm{CH}_{2} \mathrm{Cl}, 70{ }^{\circ} \mathrm{C}, 1 \mathrm{~h}, 79 \%$; (e) TBDPSCl, imidazole, DMAP, DMF, $24 \mathrm{~h}$ 84\%; (f) $\mathrm{SeO}_{2}$, dioxane, reflux, $24 \mathrm{~h}, 81 \%$; (g) $\mathrm{MnO}_{2}, \mathrm{CH}_{2} \mathrm{Cl}_{2}, 15 \mathrm{~h}, 90 \%$; (h) TBAF, THF, 2 h, $74 \%$.

this type of regioselective demethylation. ${ }^{26}$ After considerable experimentation, the Arai-Nishida protocol with $\mathrm{NbCl}_{5}$ proved to be the method of choice. ${ }^{27}$ Eventually, treatment of $\mathbf{1 8}$ with $\mathrm{NbCl}_{5}$ in 1,2-dichloroethane at $70{ }^{\circ} \mathrm{C}$ facilitated regioselective demethylation, affording phenol $\mathbf{1 9}$ as a sole product in $79 \%$ yield. Protection of the two hydroxy groups with TBDPSCl and imidazole provided bis-TBDPS ether 20 in $84 \%$ yield. Allylic oxidation of 20 with $\mathrm{SeO}_{2}$ followed by oxidation of the resulting allylic alcohol with $\mathrm{MnO}_{2}$ afforded enone 21 in $73 \%$ yield. Finally, removal of the two TBDPS protecting groups with TBAF completed the asymmetric synthesis of descurainin (1). The optical rotation of the synthetic material $1(95 \%$ ee $),{ }^{28}[\alpha]_{\mathrm{D}}{ }^{23}$ +327.5 ( c $0.55, \mathrm{MeOH})$, was greatly different from the literature value $\left[\right.$ lit. $\left.^{1}[\alpha]_{\mathrm{D}}{ }^{23}+1.7(c 0.23, \mathrm{MeOH})\right]$, albeit with the same sign. This observation suggests that $\mathbf{1}$ could be biosynthesized in nearracemic form like natural product 2 .

In summary, we have achieved the first catalytic asymmetric synthesis of descurainin. The key features of this synthesis include an efficient construction of the 8-oxabicyclo[3.2.1]octane skeleton employing $\mathrm{Rh}_{2}(R \text {-TCPTTL })_{4}$-catalyzed tandem formylderived carbonyl ylide formation-1,3-dipolar cycloaddition, a stereoselective alkene hydrogenation, an oxidation with Fremy's salt and a regioselective demethylation with $\mathrm{NbCl}_{5}$ developed by the group of Arai and Nishida. Further application of the catalytic enantioselective carbonyl ylide cycloaddition methodology to asymmetric synthesis of biologically active natural products is currently in progress.

\section{Acknowledgments}

This research was supported, in part, by a Grant-in-Aid for Scientific Research on Innovative Areas (Project No. 2105: Organic Synthesis Based on Reaction Integration) from the Ministry of Education, Culture, Sports, Science and Technology, Japan. We thank S. Oka, M. Kiuchi and T. Hirose of the Center for Instrumental Analysis at Hokkaido University for mass measurements and elemental analysis.

\section{Supplementary data}

Supplementary data associated with this article can be found in the online version, at doi: $\mathrm{xxx}$.

\section{References and notes}

1. Sun, K.; Li, X.; Li, W.; Wang, J.; Liu, J.; Sha, Y. Chem. Pharm. Bull. 2004, 52, 1483-1486.

2. Wen, Y.; He, S.; Xue, K.; Cao, F. Zhong Cao Yao 1986, 17, 122; Chem. Abstr. 1986, 105, 75884m.

3. Yin, H.-B.; He, Z.-S.; Ye, Y. J. Nat. Prod. 2000, 63, 1164-1165.

4. (a) Snider, B. B.; Grabowski, J. F. Tetrahedron Lett. 2005, 46, 823-825; (b) Snider, B. B.; Grabowski, J. F. Tetrahedron 2006, 62, 5171-5177.

5. For books and reviews on 1,3-dipolar cycloadditions of carbonyl ylides, see: (a) Padwa, A.; Weingarten, M. D. Chem. Rev. 1996, 96, 223-269; (b) Doyle, M. P.; McKervey, M. A.; Ye, T. Modern Catalytic Methods for Organic Synthesis with Diazo Compounds; Wiley-Interscience: New York, 1998; Chapter 7; (c) Hodgson, D. M.; Pierard, F. Y. T. M.; Stupple, P. A. Chem. Soc. Rev. 2001, 30, 50-61; (d) Mehta, G.; Muthusamy, S. Tetrahedron 2002, 58, 9477-9504; (e) Savizky, R. M.; Austin, D. J. In Modern RhodiumCatalyzed Organic Reactions; Evans, P. A., Ed.; Wiley-VCH: Weinheim, 2005; Chapter 19.

6. For a book and reviews on the syntheses of natural products by a carbonyl ylide cycloaddition strategy, see: (a) McMills, M. C.; Wright, D. In Synthetic Applications of 1,3-Dipolar Cycloaddition Chemistry Toward Heterocycles and Natural Products; Padwa, A., Pearson, W. H., Eds.; John Wiley \& Sons: Hoboken, 2003; Chapter 4; (b) Padwa, A. Helv. Chim. Acta 2005, 88, 1357-1374; (c) Padwa, A. J. Organomet. Chem. 2005, 690, 5533-5540; (d) Nair, V.; Suja, T. D. Tetrahedron 2007, 63, 12247-12275; (e) Singh, V.; Krishna, U. M.; Vikrant; Trivedi, G. K. Tetrahedron 2008, 64, 3405-3428; (f) Padwa, A. Chem. Soc. Rev. 2009, 38, 3072-3081.

7. For other more recent works, see: (a) Geng, Z.; Chen, B.; Chiu, P. Angew. Chem. Int. Ed. 2006, 45, 6197-6201; (b) Hirata, Y.; Nakamura, S.; Watanabe, N.; Kataoka, O.; Kurosaki, T.; Anada, M.; Kitagaki, S.; Shiro, M.; Hashimoto, S. Chem. Eur. J. 2006, 12, 8898-8925; (c) England, D. B.; Padwa, A. Org. Lett. 2007, 9, 3249-3252; (d) England, D. B.; Padwa, A. J. Org. Chem. 2008, 73, 2792-2802; (e) Lam, S. K.; Chiu, P. Chem. Eur. J. 2007, 13, 9589-9599; (f) Kim, C. H.; Jang, K. P.; Choi, S. Y.; Chung, Y. K.; Lee, E. Angew. Chem. Int. Ed. 2008, 47, 4009-4011.

8. In classification of reaction integration, tandem reaction is categorized as a time and space integration by the Yoshida group. Suga, S.; Yamada, D.; Yoshida, J. Chem. Lett. 2010, 39, 404-406.

9. (a) Hodgson, D. M.; Stupple, P. A.; Johnstone, C. Tetrahedron Lett. 1997, 38, 6471-6472; (b) Hodgson, D. M.; Stupple, P. A.; Johnstone, C. Chem. Commun. 1999, 2185-2186; (c) Hodgson, D. M.; Stupple, P. A.; Pierard, F. Y. T. M.; Labande, A. H.; Johnstone, C. Chem. Eur. J. 2001, 7, 4465-4476; (d) Hodgson, D. M.; Glen, R.; Grant, G. H.; Redgrave, A. J. J. Org. Chem. 2003, 68, 581-586; (e) Hodgson, D. M.; Labande, A. H.; Pierard, F. Y. T. M.; Expósito Castro, M. Á. J. Org. Chem. 2003, 68, 61536159; (f) Hodgson, D. M.; Brückl, T.; Glen, R.; Labande, A. H.; Selden, D. A.; Dossetter, A. G.; Redgrave, A. J. Proc. Natl. Acad. Sci. U.S.A. 2004, 101, 5450-5454; (g) Hodgson, D. M.; Glen, R.; Redgrave, A. J. Tetrahedron: Asymmetry 2009, 20, 754-757.

10. (a) Kitagaki, S.; Anada, M.; Kataoka, O.; Matsuno, K.; Umeda, C.; Watanabe, N.; Hashimoto, S. J. Am. Chem. Soc. 1999, 121, 1417-1418; (b) Kitagaki, S.; Yasugahira, M.; Anada, M.; Nakajima, M.; Hashimoto, S. Tetrahedron Lett. 2000, 41, 59315935; (c) Tsutsui, H.; Shimada, N.; Abe, T.; Anada, M.; Nakajima, M.; Nakamura, S.; Nambu, H.; Hashimoto, S. Adv. Synth. Catal. 2007, 349, 521-526; (d) Shimada, N.; Anada, M.; Nakamura, S.; Nambu, H.; Tsutsui, H,; Hashimoto, S. Org. Lett. 2008, 10, 36033606; (e) Nambu, H.; Hikime, M.; Krishnamurthi, J.; Kamiya, M.; Shimada, N.; Hashimoto, S. Tetrahedron Lett. 2009, 50, 36753678; (f) Kurosaki, Y.; Shimada, N.; Anada, M.; Nambu, H.; Hashimoto, S. Bull. Korean Chem. Soc. 2010, 31, 694-696.

11. Suga and co-workers reported enantioselective 1,3-dipolar cycloadditions of carbonyl ylides using chiral Lewis acid catalysts: (a) Suga, H.; Inoue, K.; Inoue, S.; Kakehi, A. J. Am. Chem. Soc. 2002, 124, 14836-14837; (b) Suga, H.; Inoue, K.; Inoue, S.; Kakehi, A.; Shiro, M. J. Org. Chem. 2005, 70, 47-56; (c) Suga, H.; Ishimoto, D.; Higuchi, S.; Ohtsuka, M.; Arikawa, T.; Tsuchida, T.; Kakehi, A.; Baba, T. Org. Lett. 2007, 9, 4359-4362; (d) Suga, H.; Highchi, S.; Ohtsuka, M.; Ishimoto, D.; Arikawa, T.; Hashimoto, Y.; Misawa, S.; Tsuchida, T.; Kakehi, A.; Baba, T. Tetrahedron 2010, 66, 3070-3089.

12. Very recently, Iwasawa and co-workers reported a catalytic asymmetric [3+2] cycloaddition of platinum-containing carbonyl 
ylides with vinyl ethers. Ishida, K.; Kusama, H.; Iwasawa, N. $J$. Am. Chem. Soc. 2010, 132, 8842-8843.

13. For the effective use of $\mathrm{Rh}_{2}(S \text {-TCPTTL })_{4}(4)$ in enantioselective aminations, see: (a) Yamawaki, M.; Tsutsui, H.; Kitagaki, S.; Anada, M.; Hashimoto, S. Tetrahedron Lett. 2002, 43, 95619564; (b) Yamawaki, M.; Tanaka, M.; Abe, T.; Anada, M.; Hashimoto, S. Heterocycles 2007, 72, 709-721; (c) Tanaka, M.; Kurosaki, Y.; Washio, T.; Anada, M.; Hashimoto, S. Tetrahedron Lett. 2007, 48, 8799-8802; (d) Anada, M.; Tanaka, M.; Shimada, N.; Nambu, H.; Yamawaki, M.; Hashimoto, S. Tetrahedron 2009. 65, 3069-3077.

14. Charette and co-workers recently reported highly efficient asymmetric cyclopropanation with $\alpha$-nitro diazoacetophenones using $\mathrm{Rh}_{2}(S \text {-TCPTTL })_{4}(\mathbf{4})$, where the X-ray crystal structure of 4 was determined: Lindsay, V. N. G.; Lin, W.; Charette, A. B. J. Am Chem. Soc. 2009, 131, 16383-16385.

15. Iwabuchi and co-workers recently reported highly enantioselective intramolecular aza-spiroannulation onto an indole nucleus catalyzed by $\mathrm{Rh}_{2}(S \text {-TCPTTL })_{4}$ (4). (a) Sato, S.; Shibuya, M.; Kanoh, N.; Iwabuchi, Y. J. Org. Chem. 2009, 74, 7522-7524; (b) Sato, S.; Shibuya, M.; Kanoh, N.; Iwabuchi, Y. Chem. Commun. 2009, 6264-6266.

16. Shimada, N.; Hanari, T.; Kurosaki, Y.; Takeda, K.; Anada, M.; Nambu, H.; Shiro, M.; Hashimoto, S. J. Org. Chem. 2010, 75, 6039-6042.

17. (a) Nakamura, S.; Sugano, Y.; Kikuchi, F.; Hashimoto, S. Angew. Chem. Int. Ed. 2006, 45, 6532-6535; (b) Snider, B. B.; Wu, X.; Nakamura, S.; Hashimoto, S. Org. Lett. 2007, 9, 873-874.

18. Recently, Peterson and co-workers reported that compound 2 could be produced from glucose, glycine, and ferulic acid in $3 \%$ yield in a simulated backing model system $(10 \%$ moisture at $200{ }^{\circ} \mathrm{C}$ for $\left.15 \mathrm{~min}\right)$. They also reported that 2 suppressed the bacterial lipopolysaccharide-mediated expression of two prototypical pro-inflammatory genes, inducible nitric oxide synthase and cyclooxygenase (COX)-2. Jiang, D.; Chiaro, C.; Maddali, P.; Prabhu, K. S.; Peterson, D. G. J. Agric. Food Chem. 2009, 57, 9932-9943.

19. Assuming that descurainin (1) might also possess the same absolute configuration as that of natural product 2 , we used $\mathrm{Rh}_{2}(R$ TCPTTL $)_{4}(\mathbf{5})$ instead of $\mathrm{Rh}_{2}(S \text {-TCPTTL })_{4}(\mathbf{4})$.

20. The absolute configuration of ent $\mathbf{- 8}$ was determined to be $(1 S, 5 S)$ by comparison of the sign of the optical rotation with the data reported in ref. 16
21. Hodgson and co-workers reported exo-selective alkene hydrogenation of 8-oxabicyclo[3.2.1] oct-6-en-2-one derivatives. (a) Hodgson, D. M.; Avery, T. D.; Donohue, A. C. Org. Lett. 2002 4, 1809-1811; (b) Hodgson, D. M.; Le Strat, F.; Avery, T. D.; Donohue, A. C.; Brückl, T. J. Org. Chem. 2004, 69, 8796-8803.

22. $\left(\mathrm{KSO}_{3}\right)_{2} \mathrm{NO}$, often referred to as Fremy's salt, has been used in the preparation of $o$ - and $p$-benzoquinones, naphthoquinones, and some polycondensed quinones and in the oxidation of indolines. For a review, see: (a) Zimmer, H.; Lankin, D. C.; Horgan, S. W. Chem. Rev. 1971, 71, 229-246. For recent examples of oxidation with Fremy's salt used in the total syntheses of natural products, see: (b) Alvarez-Manzaneda, E.; Chahboun, R.; Cabrera, E.; Alvarez, E.; Haidour, A.; Ramos, J. M.; Alvarez-Manzaneda, R.; Hmamouchi, M.; Es-Samti, H. Chem. Commun. 2009, 592-594; (c) Nielsen, L. B.; Slamet, R.; Wege, D. Tetrahedron 2009, 65, 4569-4577; (d) Ishii, S.; Fujii, M.; Akita, H. Chem. Pharm. Bull. 2009, 57, 1103-1106; (e) Inoue, K.; Ishikawa, Y.; Nishiyama, S. Org. Lett. 2010, 12, 436-439.

23. LaLonde and Zhang reported installation of a hydroxy group at the C5' position of $\alpha$-conidendrin possessing a 4'-hydroxy-3'methoxybenzene ring via formation of $o$-quinone with Fremy's salt and subsequent reduction with $\mathrm{Na}_{2} \mathrm{~S}_{2} \mathrm{O}_{4}$. LaLonde, R. T.; Zhang, M. J. Nat. Prod. 2004, 67, 697-699.

24. The reaction of $\mathbf{1 5}$ with $\mathrm{MeI}$ (1.0 equiv) and $\mathrm{K}_{2} \mathrm{CO}_{3}$ (1.0 equiv) in acetone at room temperature for $12 \mathrm{~h}$ gave a mixture of nonselectively methylated products, bis-methylated product $\mathbf{1 6}$ and substrate $\mathbf{1 5}$.

25. Cacchi, S.; Morera, E.; Ortar, G. Tetrahedron Lett. 1984, 25, 4821-4824.

26. (a) Kuhn, M.; Keller-Juslén, C.; von Wartburg, A. Helv. Chim. Acta 1969, 52, 944-947; (b) Thurston, L. S.; Irie, H.; Tani, S.; Han, F.-S.; Liu, Z.-C.; Cheng, Y.-C.; Lee, K.-H. J. Med. Chem. 1986, 29, 1547-1550; (c) Klein, L. L.; Yeung, C. M.; Chu, D. T.; McDonald, E. J.; Clement, J. J.; Plattner, J. J. J. Med. Chem. 1991, 34, 984-992; (d) Kamal, A.; Laxman, N.; Ramesh, G. Bioorg. Med. Chem. Lett. 2000, 10, 2059-2062; (e) Kamal, A.; Kumar, B. A.; Arifuddin, M. Tetrahedron Lett. 2003, 44, 8457-8459.

27. (a) Arai, S.; Sudo, Y.; Nishida, A. Synlett 2004, 1104-1106; (b) Sudo, Y.; Arai, S.; Nishida, A. Eur. J. Org. Chem. 2006, 752-758.

28. The enantiomeric purity of the synthetic material $\mathbf{1}$ was determined to be $95 \%$ ee by comparison of the HPLC retention time with a racemic sample of $\mathbf{1}$, which was prepared according to the literature. See ref. $4 \mathrm{~b}$. 